\title{
THE ROLE OF BELGADE WINE FAIR BEOWINE ON DEVELOPMENT OF WINE TOURISM IN SERBIA
}

\author{
Goran Jevićc , Jelena Jević2 ${ }^{2}$ Stevan Barovic ${ }^{3}$
}

\begin{abstract}
Wine events have a significant role in promoting and developing wine tourism. There are even thirty events related to wine and wine tourism in Serbia, however they are not well-researched and well-known. This paper will analyse wine event BeoWine Fair 2015. The aim of the paper is to research socio-demographic characteristics of the visitors, motivating factors for visiting and overall impression on the fair and tasted wine during the international fair BeoWine Fair 2015. The paper is based on the primary research conducted during the event from 19 to 22 February 2015. The survey was conducted individually and the questionnaire was distributed to 120 visitors. The questionnaire consists of two parts and nineteen questions in total. This research offers answers to the questions regarding the profile of consumers attending this event and their attitudes regarding the event itself. The paper consists of three parts. The first part is called 'The Role of Events in Wine Tourism', the topic of the second section is 'Wine Festivals in Serbia' and the third is related to the 'Survey of Visitors' coming to Belgrade fair BeoWine Fair 2015. The methods applied in this paper are desk and field research, and statistics for the data collected during the survey.
\end{abstract}

Key words: events, wine tourism, BeoWine Fair 2015

JEL: $L 66, L 83, Q 10, Z 30$

\section{Introduction}

Event tourism as part of special interest tourism is gaining importance when it comes to creating tourist offer and development strategy not only for certain destinations but also whole regions and countries (Štetić, 2007). There are thirty wine events in Serbia. Some of them are festivals, while others are fairs or exhibitions. Wine fairs represent a very important segment within enotourism and their aim is to promote sale, inform the consumers and

1 Goran Jević, M.A., Assistant, College of Tourism, Bulevar Zorana Djindjića no. 152a, Belgrade, Phone: +381 1126982 05, E-mail: jevicg@visokaturisticka.edu.rs

2 Jelena Jević, M.A., Assistant, College of Tourism, Bulevar Zorana Djindjića no. 152a, Belgrade, Phone +381 1126982 05, E-mail: jelenaz@,visokaturisticka.edu.rs

3 Stevan Barović, Director, Hotel HERITAGE, Mije Kovčevića no. 7a, Belgrade, E-mail: director@heritagebelgrade.com

EP 2016 (63) 4 (1347-1363) 
research markets, especially if there is a new product on offer. At the same time, fairs are a good opportunity to invite consumers to visit a certain wine region and to become familiar with the terroir and wine producing technology used in a winery. Belgrade wine fair enables visitors to discover in one place the offer of an array of wineries from the country and the region. Well-developed accompanying programme of the event consisting of workshops, lectures, seminars (presented by the Wine Tourism Academy, a short course given by the Sommelier Association, etc.) contributes immensely to the practical and scientific research field (Mihajlović, 2016). From the aspect of wine tourism, wine fair in Belgrade is a very significant event since it promotes enotourism and wine routes in Serbia.

\section{The Role of Events in Wine Tourism}

According to Getz (2008) events are an important motivating factor in tourism, and figure prominently in the development and marketing plans of most destinations. The roles and impacts of planned events within tourism have been well-documented, and are of increasing importance for destination competitiveness. Yet it was only a few decades ago that 'event tourism' became established in both the tourism industry and in the research community, so that subsequent growth of this sector can only be described as spectacular. In the process of creating the concept of event, it is absolutely necessary to consider multiple factors, the most important being the purpose of an event although it is greatly related to the theme and place of an event. In some cases, defining the purpose of an event may be very difficult (Wagen, White, 2010). More often than not, reaching the purpose induces 'stress' to a destination where an event takes place, so Douglas, Deeret, (2001) warn that the volume of tourism may have negative impact, especially on local communities, such as demonstration effect or product commodification, and underline the imperative that the event management should include monitoring and evaluating positive and negative outcomes of the event.

The increasing importance of events in contemporary tourism is also mentioned by Jovanović (2013), underscoring the relation to culture (music festivals, concerts, exhibitions, competitions, etc.), sports (regatta, water-ski, etc.), tradition (carnivals, folklore, etc.). Rabotić (2013: 135) considers that events bringing tourists to a destination can have cultural, art, sports, entertainment, business, and even political characteristics. Based on that, the author concludes that event tourism is in fact a segment of an existing type of tourism, depending on the theme of an event. Thus, attending a sports or cultural event can be classified as a form of sports and cultural tourism, respectively.

Therefore, visits to wine festivals can be regarded as part of wine tourism, as this also confirmed by Hall et al. (2000) in the frequently-quoted definition of wine tourism "Wine tourism includes visitation to vineyards, wineries, wine festivals and wine shows for which grape wine tasting and/or experiencing attributes of a grape wine region are the prime motivating factors for visitors".

Numerous authors (e.g. Getz et al., 2000; Carlsen et al., 2000; Hall et al., 2000; Youan et al., 2006), state the increasing infulence of wine events to the development of wine tourism and tourism in general. According to them, wine festivals have a role in promoting the appeal 
of a wine region, improving a tourist destination image, influencing customer loyalty to certain wineries and their wines, attracting tourists, maintaining a positive destination image, functioning as animators and catalysts. Researchers have also underlined the influence of wine festivals on the sales of certain wine brands.

Frequently, wine tourists do not come for a wine event only, but they tend to visit other attractions of a wine region. For instance, visitors to Smederevska jesen usually go to see the Fortress of Smederevo or a winery in Smederevo region, visitors to Berbanski dani in Palić often stop in Subotica, a farm or a winery in Horgoš-Subotica region, etc.

Tourist receipts at the local community holding a festival go largely to wineries as part of direct sales of wines excluding distribution charges or hefty margins. At first, wine tourists taste several wine varietals and then, in majority of cases, they decide to buy certain wine, the one they prefer according to the taste and quality, but also the price. Providing a festival is locally organised, wineries will have no costs incurred and do not have to pay for the stall. In addition to wine cellars, the greatest profit shares from a wine festival go to local souvenir shops and restaurants, and hotels to a lesser extent. Analyses of some Serbian wine events, e.g. Pudarski dani in Irig through surveys and interviews in 2014, show that the greatest profit was made by local producers selling home-made jam, juice, chutney, honey, as well as producers selling cooked food (e.g. sausages, burgers, buns with clotted cream).

As stated by Carlsen and Getz (2006), wine events can also maintain the profile of a wine region in key markets and help wineries and wine regions to be recognized in the competitive market. Inclusion of events and festivals in marketing, branding and promoting wine regions has become so significant that almost all wineries and wine regions world-wide have become hosts to wine festivals and/or wine tourism events.

This can be validated on the example of Serbia as well, where every wine region out of eight in total has at least one wine festival per year. The leader is the wine region of Fruška gora, with as many as seven festivals per year.

Organizing wine events can have special importance for new, unestablished wine regions since gastronomic events usually receive good media coverage, which has an important role in promoting and branding tourist destinations. The number of TV shows and magazines dedicated to grape growing and wine making has increased recently and wine events have become interesting topic for them.

Szabo et al. (2014) went even further in stating that wine festivals and fairs have a positive impact to the whole wine culture and behaviour of the future generations of wine consumers, also that enotourism and wine events are the most important ways of introducing consumers to certain wines.

Camburne and Macionis (2000) analyse the relevance of two festivals, Jazz and Canberra District Vintage, as they develop new markets for attracting a larger number of visitors and generate significant cellar door sales. Apart from motivating visits, the festivals have a long term effects on visitors regarding brand loyalty and relation to a winery. The authors focus on another festival, Vintage Festival, which has increased the number of tourists in the 
Canberra district. The festival encourages small wineries to take part in the event, including a series of themed events: wine education, introduction to wine producers, participation in the winemaking process, socializing, entertainment (music events), food and wine.

Frochot (2000) focuses on a festival in Burgundy, Confrerie des Chevaliers du Tastevin, held every fourth weekend in January. This festival mainly aims at local and national markets and gathers between 100000 and 130000 visitors every year. The author analyses other wine events in France and emphasises the region of Alsace with well-developed wine events, attracting German and Belgian tourists in particular.

Only a small number of festivals in Serbia can be labelled as international. The largest festival related to grape growing and wine making is Grožđenbal held in Vršac every September. There are between 100000 and 150000 visitors each year. According to the official data taken from the Tourist Organisation of Vršac, there were 140000 visitors during four days of the festival in 2015. According to the data available on the municipality's website, in 2012 the number of visitors exceeded 150 000, with even 15000 coming from Romania. This festival is held every year, during the third weekend in September. The festival is dominated by wine producers from Vršac region and it is an excellent opportunity for the wine producers to present indigenous white grape wine variety Kreaca. This variety is of great significance to the wine tourism of the region, and to Grožđenbal as well. Wine tourists coming to the festival have the opportunity to taste wines of this variety produced by different wineries all at same place. Ćirić (2014) states that' Kreaca is grown in Southern Banat since the beginning of grape growing. Today it is grown in Hungary, Romania and Serbia (vineyards of Vršac). It is distinguished by smooth and refreshing flavour, resembling Italian Riesling, both usually used in coupage. Due to the resemblance, in Hungary it is often called Banat Riesling. Visitors of the festival have a chance to see other tourist attractions of this region, some of the wine cellars on Vršac wine route (wine cellars Nedin-Gudurica, Selekta-Gudurica, Sočanski-Veliko Središte, and winery Vinik-Vršac), heritage museum, Vršac tower, Vladičanski castle, Malo Središte monastery, Catholic church, etc. Dedjanski (2011) states that the most wine cellars are situated in ethno village Gudurica which has the richest tradition of wine-making in our country.

A number of authors researching wine festivals also analysed the motivation of visitors, whether they come for entertainment, wine tasting, relaxation, socializing, wine education, introduction to new varieties and flavours or something else.

Both academic and practical research tend to conclude that wine festival visitors differ from general wine consumers. Some researchers show that wine festivals attract younger, inexperienced wine consumers, willing to learn about wine in a more casual and less strict surrounding than a wine class or winery (Dodd et al., and Houghton quoted in Fountain 2014: 2). On the other hand, other researchers claim that focus on entertainment during wine festivals and events draws too casual visitors and such atmosphere may drive away serious wine consumers (Houghton quoted in Fountain 2014). If there is a difference between motivating factors of visitors to a wine region and a wine festival, it can be shown by comparing research presented in this paper on the example of wine event BeoWine with 
the analysis of motivating factors for visitation. The author of the paper conducted research related to visits to the wine region of Vršac in 2009. The research showed that tourists visit the region primarily for leisure, entertaining and relaxing with $63 \%$. On the other hand, the most dominant motivating factor for visiting BeoWine Fair was wine tasting with $55 \%$ while socialising, entertaining and relaxing came second with $24.2 \%$ (Table 8).

Pivac (2012) divides wine tourists into three categories based on their motivation to visit a winery or their expectations. Accidental or curious tourists need to feel pleasant at the entrance to a winery, not intimidated, and to be informed on the wine in an amusing and casual manner. Interested wine tourists need to find wine and information unavailable in their local wine shops and want to discover something new. Dedicated wine tourists want more information than interested wine tourists and look for a chance to develop their inclination even further, to be recognized as connoisseurs and to taste and buy the latest or rarest wines.

Hall and Getz (quoted in Taylor 2006) emphasize that wine festivals and events organized in urban locations are of particular interest to researchers and wine industry due to the venue, size, economic impact and media coverage.

Yuan et al. (2006) noticed that a wine festival, if held at an attractive venue, may draw visitors without previous plans to visit a winery so they cannot be classified as wine tourists. Taylor and Shanka (quoted in Youan et al., 2006) study how a choice of a venue contributes to the overall success of a wine festival. When a regional wine festival is held in a city centre, it facilitates the connection between the rural (wineries and their product) and the urban (infrastructure and links to modern lifestyles).

According to Park (quoted in Fountain, 2014), attending a wine festival in a rural wine region generally requires more planning, organisation and commitment than attending a wine festival in the city where one lives. The matter of additional expenses should be added here. Organising a visit to a wine festival requires free time and financial means for the travel. Festivals usually last a couple of days so in order to attend them, a tourist needs at least one afternoon off work and it is almost impossible to get it with modern office hours. On the other hand, travelling to a rural destination can be quite expensive.

One of the festivals aiming at presenting wine regions and wines to potential wine tourists is Belgrade festival dedicated to wine - BeoWine Fair and it will be analysed in the following section.

\section{Wine Festivals in Serbia}

Fenich (2010) claims that understanding one's own target market is one of the keys to the success of an event. The crucial role in planning and marketing an event is recognizing the audience i.e. participants. An event has to be based on general needs and demands of its target market.

Events have a great importance for tourism in Serbia and Belgrade and as such they have been identified in tourism strategies of Serbia and Belgrade. Thus, Tourism Strategy for Belgrade considers events "as extremely attractive tourist product for multiple, usually immeasurable, 
benefits for the local community/destination".

The first interim report of Tourism Strategy for Serbia states that "Serbia can succeed in attracting a considerable number of inbound tourists in a very short period and without great financial investment. In other words, events should be another 'quick win' activity as the growth potential of this product has marketing capacity for additional promoting of Serbia and increasing customer loyalty for Serbia".

Wakefield and Blodgett (quoted in Mason M., Paggiaro A., 2012) claim that "when compared to other kinds of services, which are more utilitaristic or function-oriented, food and wine events share a hedonistic nature, mainly targeted at emotions".

As stated by Jovanović (2013) "food and wine festivals are recognisable, popular events held all over Serbia. Grožđenbal in Vršac has as many as 150000 visitors, and other festivals in Sremski Karlovci and Topola are also well attended".

According to Bjeljac (2010) "events dedicated to grapes are organised towards the end of September or beginning of October and mid-February. Considering that grape growing is one of the highly developed agricultural sectors in Serbia, vineyard regions are connected into an attractive tourist destination of Serbia - Wine routes of Serbia. These events have a long tradition - with some interruptions, they have been held since the second half of the $19^{\text {th }}$ century (Vršac, Sremski Karlovci, and Smederevo)".

Pivac (2012) in the study 'Wine Tourism in Vojvodina' states that wine and food events provide additional benefit to wineries:

- $\quad$ wineries get a cheaper (and sometimes more profitable) way of promoting their brand to new consumers,

- $\quad$ wine regions establish a clearer and stronger identity,

- wine producers have the opportunity to influence their consumers and to receive the feedback from them,

- wine events, maybe more than other types of tourism, enable wine producers to access targeted consumers or interested buyers

Jovanović et al. (2015) considered that wine events could be a good foundation for wine tourism, but unfortunately they still have only local character in Serbia. If they were at regional or international level, they could attract a greater number of domestic and inbound tourists. Events and festivals establish the recognition of a region. There is a large number of small-scale events held in wine regions during grape picking season: Pudarski dani in Irig, Vršačka berba, Sajam vojvođanskih vina in Inđija, Berbanski dani i zlatne ruke in Subotica, etc. Vlahović et al. (2012) also gives some of the most popular events in Serbia dedicated to wine and grapes ponts out that wine tourism and events celebrating wine/grape are complex promotional activities where producers are intensively involved.

According to the official event calendar of Tourist Organisation of Serbia for 2015, there are precisely thirty events dedicated to wine and enotourism. The best known and most 
attended among them are International Wine Fair BeoWine Fair (Belgrade, February 19), Wine Festival Vinofest (Vršac, March 20), International Wine Festival Interfest (Novi Sad, June 18-20), Grape Picking (Vršac, September 17-20), Picking Days Berbanski dani (Palić, September 19-20) Grape picking Karlovačka berba grožđa (Sremski Karlovci, end of September), Smederevska jesen (Smederevo, during September), Picking days Župska berba (Aleksandrovac, during September), Belgrade Wine Salon (Belgrade, December 11-12), Winterfest (Kopaonik, March). Apart from Grožđenbal in Vršac, the majority of domestic and inbound visitors go to the following festivals: Karlovačka berba grožđa held every last week in September. There are around 100000 visitors, mostly domestic from Southern Banat and Srem. The majority of them come from Novi Sad and its surroundings. Smederevska jesen is the oldest tourist event in Serbia, dating back to 1899. This event is visited by 50000 people every year, mostly from the Danube region but also from Belgrade and its surroundings. Tourists from Belgrade can reach this event by a special vintage train called Romantika running once a day during the festival. Župska berba is an event held every September in Aleksandrovac. The event started in 1963 and the main attraction is undoubtedly the wine fountain pouring red wine instead water. This event attracts tens of thousands of people.

Two best-known festivals in Belgrade offering wine products from numerous wineries to a vast market of Belgrade are Belgrade Wine Salon and Belgrade International Wine Fair.

Belgrade Wine Salon is one of the best-organised wine festivals in Serbia as it includes a large number of accompanying programmes consisting of workshops, presentations, lectures, promotions, special and exclusive wine tasting. This salon gathers a great number of wineries from Serbia and the region and each year there are a couple of world-renowned wineries present. The salon was established in 2004 and offers an excellent opportunity to wine producers to present their wines to the market of Belgrade as the most important wine market in Serbia and in South-eastern Europe.

The salon is held in December at the hotel Hyatt Regency Belgrade and it is divided into the main and accompanying programmes, simultaneously held in several halls, including wine and food tasting workshops, lectures, promotions, themed lunch and dinner and business meetings.

Belgrade Wine Fair has been held since 2010, coinciding with the Tourism Fair, the most attractive and most-attended tourism fair in South-eastern Europe, confirming the relevance of this wine event to the tourism industry. Apart from wineries from Serbia, the wine and equipment is presented by producers from Croatia, Slovenia, Macedonia, Bosnia, Montenegro, Portugal, Sweden, Bulgaria, Austria, Greece, Italy, and France. In addition to exhibition and sales, this fair organizes competitions for the best wines in the fair and best Serbian wines in eight categories as decided by wine expert jury.

Belgrade Wine Fair is one of the biggest and most-attended in the region, and by its visitors profile it belongs to the events like VINOCOM Zagreb, International Wine Fair Ljubljana, Sarajevo Wine Fest, and Wine Exhibition and Fair Budapest. According to the official data taken from the website www.sajam.co.rs, there were 141 exhibitors, 90 Serbian and 51 international from 11 countries. During the four days of the event, there were 69508 visitors. 
Table 1. Number of exhibitors and visitors at Belgrade Wine Fair

\begin{tabular}{|l|l|l|l|}
\hline BeoWine Fair & $\mathbf{2 0 1 2}$ & $\mathbf{2 0 1 4}$ & $\mathbf{2 0 1 5}$ \\
\hline Visitors & 62500 & 62604 & 69508 \\
\hline Exhibitors & 118 & 143 & 141 \\
\hline Serbian exhibitors & 81 & 104 & 90 \\
\hline International exhibitors & 37 & 39 & 51 \\
\hline Countries represented & 13 & 13 & 11 \\
\hline
\end{tabular}

Source: Author's calculation according to www.sajam.co.rs

It is noticeable in Table 1. that there was a slight increase in the number of visitors in 2014 compared to 2012 but also the number of exhibitors went up by 25 so that there were as many as 143 exhibitors in 2014. When 2015 is compared to 2014, it can be concluded that the number of exhibitors is almost the same, but the number of Serbian exhibitors was reduced whereas the number of international exhibitors was increased and it amounted to 51 in 2015. The number of visitors was increased by almost 7000 and there were 69508 people visiting the wine fair in 2015. Rising trend of visitors can point to the fact that visitors recognized the wide selection and lower prices so therefore the growing interest in wine tasting and buying is not surprising. A good indicator is that there was an increase in the number of international exhibitors but it is worrying that there was a decline in the number of exhibitors from Serbia. This is not so surprising since the prices of stalls in Belgrade fair are exorbitant and this trend is to be expected to continue unless the management of Belgrade fair changes the prices in the future. Exhibiting at the wine fair is too expensive for an average winery from Serbia even if the sales are very good during the event. In order to reduce the costs of exhibiting, a couple of wineries use the same stall for presenting their wines and the Association of Winemakers from Sumadija are a good example of joint presentation at BeoWine Fair. This association gathers a dozen of wineries.

Association of winemakers and grape growers of Serbia - VIVIS and the company Srpsko vino are the coorganizers of the wine fair.

Regarding the number of visitors reaching almost 70 000, it can be said that the wine fair can be classified as a larger event. However, bearing in mind that this number is related also to the visitors to the tourism fair, the actual number has to be reduced so this event can be considered as a mid-size event but most-attended wine event in Serbia. According to Getz's triangle of tourist demand and value (2008) and the classification of events into mega, periodic/hallmark, regional and local, it can be concluded that BeoWine Fair belongs to the range of regional events both according to the number of visitors and exhibitors. Regional events are held only once or at a certain interval and have a medium tourist demand.

From the point of view of time and venue, it may be said that the wine fest is ideally allocated as it takes place at the lower level of Hall 2, the space in the middle of Belgrade fair premises. It also coincides with the tourism fair so that the visitors coming for travel agencies or tourist organizations can visit Hall 2 and attend BeoWine Fair as well.

The list of exhibitors includes the renowned wineries from Serbia and the visitors have the 
opportunity to taste the wines from wine cellar Aleksandrović, Radovanović, winery Zvonko Bogdan, Kovačević, Rubin from Kruševac, wine house Spasić, winery Ivanović, etc.

The fair is held in February every year and that month is traditionally known as the month of winemakers as it is the time to celebrate St Tryphon, the patron saint of grapevine and grape growing and it is the month for poring and drinking new wine.

The entrance ticket of $€ 2.5$ is certainly competitive considering that it includes free wine tasting and possibility to enter the tourism fair being held at the same time.

\section{BeoWine Fair - Survey}

\section{Research Methodology}

The survey was conducted on visitors to BeoWine Fair in 2015, a four-day event organized by Belgrade Fair every year in Belgrade. This event was established in 2010 and represents the greatest event of its kind in the region with wineries from Serbia and abroad presenting their wines to visitors. Four students from the College of Tourism together with the author of the paper conducted the survey by direct interviews using a prepared and defined questionnaire. The total of 120 valid responses was collected.

\section{Data processing}

Data processing used statistical programme SPSS and its operations. Descriptive statistics methods were applied, including calculating frequency and percentage, as well as the mean value and standard deviation of responses.

The analysis of the differences among group means was applied (ANOVA - Analysis of Variance, the mathematical and statistical process of testing statistical significance of the differences among means taken from three and more (sub) samples). It was used to test the significance of the difference between some means (from dependant variables) between subcategories of each independent variable (F coefficient).

The data collected in the questionnaires were processed by the computer programme SPSS (Statistical Package for the Social Sciences) version 22.0.

\section{Sample Characteristics}

The survey was conducted on 120 respondents, visitors to the Belgrade Wine Fair BeoWine Fair 2015. The conclusion from (Table 2.) is that there is a larger number of male visitors $65 \%$ compared to $35 \%$ of female visitors. The greatest number of respondents $(36.7 \%)$ is within 18-30 age group. Regarding the education level of respondents, the majority of visitors had higher education (around 2/3) and that as many as $36.7 \%$ have a faculty degree. It can be observed that over $62 \%$ are persons between the age of 18 and 40, implying that younger persons dominate as visitors to BeoWine Fair. A little over a half come from Belgrade while $38.3 \%$ come from other places in Serbia and 7.5\% come from abroad, mostly from former Yugoslavian countries. By comparing domestic and international visitors, it is obvious that 
the majority is domestic while international are by far fewer. The data confirmed the stated fact that BeoWine Fair is within the range of local or regional events and that the visitors coming from abroad are mostly from Romania, Bulgaria, Slovenia and Croatia and other neighbouring countries, and most often they came to the fair for business.

Table 2. Sociodemographic characteristics of respondents

\begin{tabular}{|c|l|c|c|}
\hline \multicolumn{2}{|c|}{} & \multirow{2}{*}{ Variable } & \multicolumn{2}{c|}{ Sample } \\
\cline { 2 - 4 } Gender & Male & 78 & Percent \\
\cline { 2 - 4 } & Female & 42 & $65.0 \%$ \\
\hline \multirow{5}{*}{ Age Group } & Up to 18 & 4 & $35.0 \%$ \\
\cline { 2 - 4 } & From 18 to 30 & 44 & $3.3 \%$ \\
\cline { 2 - 4 } & 31 to 40 & 31 & $36.7 \%$ \\
\cline { 2 - 4 } & 41 to 50 & 31 & $25.8 \%$ \\
\cline { 2 - 4 } & 51 to 60 & 7 & $25.8 \%$ \\
\cline { 2 - 4 } & 61 and over & 3 & $5.8 \%$ \\
\hline \multirow{5}{*}{ Education } & Primary school & 1 & $2.5 \%$ \\
\cline { 2 - 4 } & High school & 38 & $0.8 \%$ \\
\cline { 2 - 4 } & College & 37 & $31.7 \%$ \\
\cline { 2 - 4 } & Faculty & 44 & $30.8 \%$ \\
\hline \multirow{5}{*}{ Residence } & Belgrade & 65 & $36.7 \%$ \\
\cline { 2 - 4 } & Serbia & 46 & $54.2 \%$ \\
\cline { 2 - 4 } & Abroad & 9 & $38.3 \%$ \\
\hline
\end{tabular}

Source: Author's calculation

If available sample characteristics of wine festivals around the world are compared with the ones for BeoWine Fair, it can be concluded that research results are very similar with the exception of the gender of respondents, for instance, the research by Yuan et al. (2005) of "Vintage Indiana Wine and Food Indianapolis" in 2003 showed female respondents dominated with $63.7 \%$ to only $35.9 \%$ male. Other characteristics are matching with this research, so $76 \%$ have graduated from a college or faculty. Respondents were younger, $29.5 \%$ in the $21-29$ age group and $22.6 \%$ in the $30-39$. Regarding the motivating factor, more than a half (56\%) stated enjoying a special event, its festive atmosphere and entertainment. $27 \%$ of respondents were focused on wine and their primary reason for the visit was wine exclusively.

\section{Research Results}

Profiling wine tourists according to Mitchell et al. (2000) is beneficial to producers and wine managers as they can focus efficiently on potential visitors and wine consumers. Some researches in New Zealand point to considerable differences between visitors based on the regions they come from, therefore their countries. This is extremely relevant since it shows the fact that a profile of a wine tourist from a certain region does not have to be identical to another region. 
The answer to the first question should show whether tourists are visiting the festival for the first time or they have already been to BeoWine Fair. As it can be seen from Table 3, as many as $65.8 \%$ have visited the event before, implying that previous BeoWine Fair events were well-organised with wineries offer at a satisfactory level.

Table 3. Previous visits to wine fair

\begin{tabular}{|l|c|c|}
\hline & Frequency & Percent \\
\hline Yes & 79 & $65.8 \%$ \\
\hline No, this is the first time & 41 & $34.2 \%$ \\
\hline
\end{tabular}

Source: Author's calc3ulation

It can be concluded from Table 3. that BeoWine Fair has a large number of loyal visitors. The fact that return visitors dominate entails that this event has potential and interesting programme appealing to visitors to come again, but also the need to retain loyal customers, which requires less effort and funding than attracting new consumers.

Considering that wine fair BeoWine Fair coincides with the tourism fair, the question was whether they came to visit wine or tourism fair (the survey was conducted in $2 \mathrm{~b}$ Hall with only wine exhibitors) so the question was: "Was your primary motivating factor the visit to wine fair or tourism fair?" Even $73 \%$ of respondents stated the wine fair as the primary reason, $8 \%$ chose tourism fair and $19 \%$ came to attend both the wine and tourism fair. It is to be noted that the survey was conducted exclusively in the Hall $2 \mathrm{~b}$, without the presence of travel agencies, tourist organisations, hoteliers, etc.

Table 4. Primary motivating factor

\begin{tabular}{|l|c|c|}
\hline & Frequency & Percent \\
\hline Wine fair & 88 & $73 \%$ \\
\hline Tourism fair & 9 & $8 \%$ \\
\hline Both & 23 & $19 \%$ \\
\hline
\end{tabular}

Source: Author's calculation

By analysing the accompanying persons, it can be concluded that $10.8 \%$ visitors came alone, $25.8 \%$ with a colleague, $14.2 \%$ with their partner, $39.2 \%$ with friends and $10 \%$ with their family as can be seen in the Table 4.

Table 5. Who did you come with?

\begin{tabular}{|l|c|c|}
\hline & Frequency & Percent \\
\hline Alone & 13 & $10.8 \%$ \\
\hline With colleague & 31 & $25.8 \%$ \\
\hline With partner & 17 & $14.2 \%$ \\
\hline With friends & 47 & $39.2 \%$ \\
\hline With family & 12 & $10.0 \%$ \\
\hline Total & 120 & $100.0 \%$ \\
\hline
\end{tabular}

Source: Author's calculation

EP 2016 (63) 4 (1347-1363) 
Table 5. shows that almost $90 \%$ of visitors did not come alone but with colleagues, partners, friends or family. The majority of them decided to visit BeoWine Fair accompanied by friends, which implies that wine tasting and relaxing requires some company. One of the most important questions is related to the impression that the wine fair left on visitors. The visitors evaluated the overall impression on the scale 1 to 5 (1 being absolutely negative and 5 absolutely positive).

Table 6. Evaluating overall impression of the festival - descriptive statistics

\begin{tabular}{|c|c|c|c|c|c|c|}
\hline & Frequency & Percent & $\mathbf{A S}$ & SD & MIN & MAX \\
\hline Absolutely negative & 0 & $0 \%$ & \multirow{6}{*}{4.12} & \multirow{6}{*}{0.63} & \multirow{6}{*}{2} & \multirow{6}{*}{5} \\
\hline Negative & 2 & $1.7 \%$ & & & & \\
\hline $\begin{array}{l}\text { Neither negative nor } \\
\text { positive }\end{array}$ & 12 & $10 \%$ & & & & \\
\hline Positive & 76 & $63.3 \%$ & & & & \\
\hline Absolutely positive & 30 & $25 \%$ & & & & \\
\hline Total & 120 & $100 \%$ & & & & \\
\hline
\end{tabular}

Source: Author's calculation

Table 6. shows that the festival received an overall positive grade. The average evaluation grade is 4.12 with $88.3 \%$ of respondents evaluating BeoWine Fair as positive. The high percentage of positive evaluation can be attributed to various factors but certainly the most important one is a large number of exhibitors, i.e. wide selection of wine on offer. Considering that there were over 100 wineries presenting in the same place, it is almost certain that even the choosiest visitors managed to find wine to their taste.

Table 7. Differences between domestic and inbound tourists regarding the overall impression of the festival

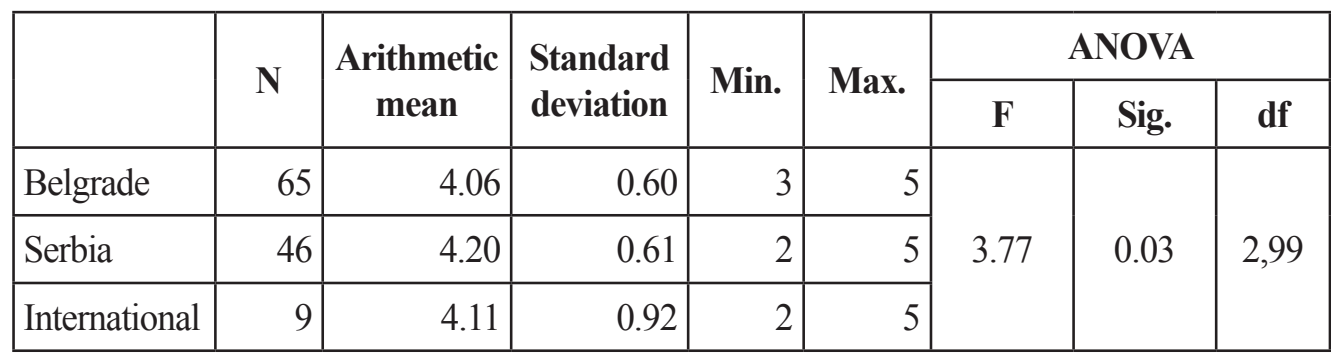

Source: Author's calculation 
Testing the significance of difference showed that repondents from Serbia evaluated the overall impression a little bit higher than visitors from Belgrade and abroad. The difference is statistically significant, with $95 \%$ reliability as it can be seen in Table 7. Table 8 . shows the primary motives for visiting the festival being wine tasting $(55 \%)$, followed by socializing, entertaining and relaxing $(24.2 \%)$, business networking $(15.8 \%)$. The least important reason for visiting a winery is buying wine with only $5 \%$.

Table 8. Primary reasons/motives for visiting wine festival

\begin{tabular}{|l|c|c|}
\hline & Frequency & Percent \\
\hline Wine tasting & 66 & $55 \%$ \\
\hline Wine buying & 6 & $5 \%$ \\
\hline Socializing, entertaining and relaxing & 29 & $24.2 \%$ \\
\hline Business networking & 19 & $15.8 \%$ \\
\hline Total & 120 & $100 \%$ \\
\hline
\end{tabular}

Source: Author's calculation

Based on the data, it can be concluded that visitors did not come to the festival only to be entertained but that they are wine admirers attending the event with the sole purpose of wine tasting.

Qualitative data from the research on wine tourists in New Zealand showed that for many of them, wine tasting and learning about wines and wine production is a way to reduce the risk related to wine buying (i.e. increasing experience and knowledge so that they can make the right decision). Similarly, relaxing as the motivating factor reveals the need to escape the urban way of life (Mitchell et al., 2000).

Table 9 shows that $80 \%$ of visitors evaluated tasted wine as good or extremely good with the average grade of 4.12. It implies that the wine on offer was of high quality. Based on some visitors' statements, it seems that there is more and more demand for small family wineries than for large wine companies. It was discovered that the fair visitors prefer red wine $(49.2 \%)$, to white $(41.7 \%)$ and rose $(9.2 \%)$. Among the red wines, the greatest favourite is Cabernet Sauvignon (33.3\%), then Merlot with 15.8\% and Vranac with $13.3 \%$. Among the white wines, the most frequent choice for drinking is Chardonnay with $35 \%$, Sauvignon Blanc (20\%), and Tamjanika with 15\%. It was encouraging to find out that Tamjanika, an old indigenous Serbian variety, was rated among the most popular white wines. The question: 'Which wine region in Serbia produces best wines?' generated the following responses: $28.3 \%$ decided for Župa, Fruška gora 26.7\%, Vršac 14.2\%, Negotin 11.7\%, Venčac 6.7\%, Palić 7.5\%, Smederevo 3,3\% and finally Knjaževac 1.7\%.

Establishing the level of interest in wine visitors is extremely important in terms of educating the consumer. Wine tasting, wine festivals, guided tours and visits to the cellar door are all part of the means by which people encounter and learn about wine (Hills, 1998 quoted in Mitchell et al., 2000). 
Table 9. Evaluation of the quality of tasted wine - descriptive statistics

\begin{tabular}{|c|c|c|c|c|c|c|}
\hline & Frequency & Percent & AS & SD & MIN & MAX \\
\hline Extremely poor & 2 & $1.7 \%$ & \multirow{6}{*}{4.12} & \multirow{6}{*}{0.81} & \multirow{6}{*}{1} & \multirow{6}{*}{5} \\
\hline Poor & 0 & $0 \%$ & & & & \\
\hline Average & 21 & $17.5 \%$ & & & & \\
\hline Good & 56 & $46.7 \%$ & & & & \\
\hline Extremely good & 41 & $34.2 \%$ & & & & \\
\hline Total & 120 & $100 \%$ & & & & \\
\hline
\end{tabular}

Source: Author's calculation

Table 10. Possibility of attending the fair next year

\begin{tabular}{|l|c|c|}
\hline & Frequency & Percent \\
\hline Yes & 106 & $88.3 \%$ \\
\hline No & 1 & $0.8 \%$ \\
\hline Maybe & 13 & $10.8 \%$ \\
\hline Total & 120 & $100 \%$ \\
\hline
\end{tabular}

Source: Author's calculation

The special delight derives from the fact that there are $88.3 \%$ of respondents willing to visit the fair again, which corresponds exactly to the $88.3 \%$ of respondents stating that BeoWine Fair left a positive impression on them (cf. Table 6.).

\section{Conclusions}

Based on the conducted research, it can be concluded that Belgrade wine fair deserves the title of one of the most popular and most-attended wine events in Serbia. The number of international exhibitors is increasing whereas the number of exhibitors from Serbia is declining which is to be taken into consideration and used for new research as it is directly related to enotourism in Serbia. The greater percentage of BeoWine Fair visitors is male. The wine fair attracted a large number of younger, educated individuals, usually coming with friends, colleagues or partners. The facts point to the need to tailor the offer for younger visitors. The majority of visitors come from Belgrade and/or abroad rather than other towns in Serbia. The impression is positive, with best grades given by visitors coming neither from Belgrade nor abroad but those from other parts of Serbia. The primary motivating factor was wine tasting, and the least important was wine buying. The visitors rated the tasted wine as very good (average grade 4.12 ) and even $88.3 \%$ of respondents plan on attending the fair again next year. The consumers prefer rose wine the least, and the most popular red is Cabernet Sauvignon and white Chardonnay. As many as $28.3 \%$ of respondents think the best wine in Serbia come from Župa. From the scientific point of view, it is considered that the paper can be useful to owners/managers of wineries in order to adjust the offer to the market demands. Even greater contribution of the paper may be to the tourist experts since it offers parameters needed for improving wine events and wine tourism in Serbia. 


\section{References}

1. Bjeljac Ž. (2010): Turističke manifestacije u Srbiji, Geografski institut"Jovan Cvijićc Srpska Akademija nauke i umetnosti, Beograd

2. Camburne B., Macionis N. (2000): Meeting the wine maker: wine tourism product development in an emergin wine region in book: Wine tourism around the worldDevelopment, management and markets, Hall M., Sharples L., Cambourne B., Macionis N., pp.81-101, Elsevier Butterworth-Heinemann

3. Carlsen J., Getz D. (2006): Strategic Planning for a Regional Wine Festival: the Margaret River Wine Region Festival in book: Global wine tourism: Research, Management and Marketing, Carlsen J., Charters, S., pp.209-224, CAB International, Wallingford, Oxfordshire, GBR

4. Ćirić Đ. (2014): Vina i vinorodni tereni Banata, Službeni glasnik, Beograd

5. Deđanski, S., Puzić, G. (2010): Menadžment razvoja vinskog turizma u Srbiji kao osnova razvoja lokalnih zajednica, Ekonomika poljoprivrede, Institut za ekonomiku poljoprivrede, vol. 57, no. 3, pp. 463-473, Beograd

6. Douglas N., Deeret, R. (2001): Special interest tourism, Wiley, Milton

7. Fenich G., (2010): Meetings, Expositions, Events, and Conventions, Pearson Education

8. Fountain J. (2014): Who's here? An exploratory study of the characteristics and wine consumption behaviours of visitors at a New Zealand wine festival, 8th Academy for Wine Business Research Conference in Geisenheim, Germany, June 28-30

9. Frochot I. (2000): Wine tourism in France: a paradox? In book: Wine tourism around the world, development, management and markets, Hall C.M., Sharples L., Camboume B., Macionis N., pp. 67-80, Butterworth-Heineman, Oxford, UK

10. GetzD.(2008): Event tourism: Definition, evolution, andresearch, Tourism Management 29, pp. 403-428, Elsevier

11. Hall C.M., Sharples L., Camboume B., Macionis N. (2000): Wine tourism around the world, development, management and markets, Butterworth-Heineman, Oxford, UK

12. Jovanović D., Muhi B., Anđelković A. (2015): Vinarije i putevi vina kao sredstvo za razvoj agroturizma u Vojvodini, Turističko poslovanje-naučni časopis, broj 15, pp. 87 93, Visoka turistička škola, Beograd

13. Jovanović V. (2013): Tematski turizam, Univerzitet Singidunum, Beograd

14. Mason M., Paggiaro A. (2012): Investigating the role of festivalscape in culinary tourism: The case of food and wine events, Tourism Management 33, pp. 1329-1336

15. Mihajlović, M. (2016): Odnos menadžmenta preduzeća i korporativnog upravljanja, Oditor, Belgrade, Serbia, vol. 2, no. 1, pp. 4-10.

16. Mitchell R., Hall M., McIntosh A. (2000): Wine tourism and consumer behaviour in book: Hall M., Sharples L., Cambourne B., Macionis N., Wine tourism around the world-Development, management and markets, pp.115-135, Elsevier ButterworthHeinemann 
17. Pivac T. (2012): Vinski turizam Vojvodine, Monografija, Prirodno matematički fakultet Novi Sad, Novi Sad

18. Rabotić B. (2013): Selektivni oblici turizma, Visoka turistička škola strukovnih studija, Beograd

19. Strategija razvoja turizma grada Beograda, (2008) Institut ekonomskih nauka Beograd

20. Strategija razvoja turizma Republike Srbije, (2005) Horwat consulting Zagreb i Ekonomski fakultet Beograd

21. Szabo Z., Komaromi-Gergely A., Szeles Z. (2014): The Role of Event Marketing in Case of the Buda Castle Wine Festival, 8th Academy for Wine Business Research Conference in Geisenheim, Germany, June 28-30

22. Štetić S. (2007): Posebni oblici turizma, Autor, Beograd

23. Taylor R. (2006): Wine Festivals and Tourism: Developing a Longitudinal Approach to Festival Evaluation, In book : Global wine tourism, J. Carlsen and S. Charters, pp.179195, CAB Internacional

24. Vlahović, B., Potrebić, V., Jeločnik, M. (2012): Preferences of wine consumers on Serbian market, Economics of Agriculture, IAE Belgrade, vol. 59, no. 1, pp. 37-49, Belgrade

25. Wagen L., White L. (2010): Events management for Tourism, cultural, business and sporting events, Pearson, Australia

26. Yuan J., Jang S., Cai L., Morrison A., Linton S. (2006) Analysis of Motivational and Promotional Effects of a Wine Festival, in book: Global wine tourism, J. Carlsen and S. Charters, pp.196 - 208, CAB Internacional

Websites

1. http://sajam.co.rs/active/sr-latin/home/details/ params/sajam id/68547.html

2. http://sajam.co.rs/active/sr-latin/home/details/ params/sajam id/43100.html

3. http://sajam.co.rs/active/sr-latin/home/details/ params/sajam id/72123.html

4. http://www.to.vrsac.com/Default.aspx? Lang=sr\&Page $=58$. BerbaGro $\% \mathrm{C} 5 \% \mathrm{BE} \% \mathrm{C} 4 \% 91 \mathrm{a}$

5. http://www.vrsac.com/system/srlatin/home/newsplus/viewsingle/ params/newsplus news id/27647.html

6. https://www.facebook.com/SalonVina/

7. www.google.rs/search?q=mapa + sajma + turizma\&biw $=1366 \& b i h=641 \&$ source $=\operatorname{lnms} \& \mathrm{tbm}=\mathrm{isch} \& \mathrm{sa}=\mathrm{X} \& \mathrm{ved}=0 \mathrm{ahUKEwiys} 7 \mathrm{H} 8$-TNAhXEbxQKHfd-B18Q AUIBigB\#imgrc $=$ Y-CSlbd 8Ua2TM $\% 3 \mathrm{~A}$ 


\title{
ULOGA BEOGRADSKOG SAJMA VINA BEOWINE NA RAZVOJ VINSKOG TURIZMA U SRBIJI
}

\author{
Goran Jevic ${ }^{4}$, Jelena Jevič́, Stevan Barovic ${ }^{6}$
}

\begin{abstract}
Abstrakt
Vinske manifestacije imaju značajnu ulogu u promociji i razvoju vinskog turizma. $U$ našoj zemlji postoji čak 30 manifestacija posvećenih vinu i vinskom turizmu, ali su još uvek nedovoljno istražene i o njima se jako malo zna. Predmet ovog rada jeste analiza turističko-vinske manifestacije Beowine 2015. Ovaj rad ima za cilj da se istraže sociodemografske karakteristike posetilaca, motivi posete sajmu kao i opšti utisak posetilaca o sajmu i degustiranim vinom na međunarodnom sajmu vina Beowine 2015. Rad je zasnovan na primarnom istraživanju koje je obavljeno za vreme trajana manifestacije Beowine, $u$ period između 19. februara do 22.februara 2015. godine. Ispitivanje je vršeno individualno. Anketnim upitnikom je obuhvaćeno sto dvadeset (120) posetilaca. Anketni upitnik se sastoji iz dva dela i ukupno devetnaest pitanja. Ovo istraživanje daje odgovore na pitanja kakav profil potrošača posećuje ovu manifestaciju i kakvi su njihovi stavovi o samom događaju. Rad se sastoji iz tri dela. Prvi deo rada nosi naziv "Uloga događaja u vinskom turizu”, predmet drugog dela rada su "Festivali vina u Srbiji”" a treći deo se odnosi na "Istraživanje posetilaca” koji su posetili Beogradski sajam vina - Beowine 2015. godine. Metode korišćene u ovom radu bazirane su na kabinetskom i terenskom istraživanju, a statističkom metodom obrađeni su podaci iz anketnog upitnika.
\end{abstract}

Ključne reči: događaji, manifestacije, vinski turizam, Beowine 2015.

4 Goran Jević, M.A., Asistent, Visoka turistička škola strukovnih studija, Bulevar Zorana Djindjića br. 152a, Beograd, Telefon: +381 1126982 05, E-mail: jevicg@visokaturisticka.edu.rs

5 Jelena Jević, M.A., Asistent, Visoka turistička škola strukovnih studija, Bulevar Zorana Djindjića br. 152a, Beograd, Telefon: +381 11 2698-205, E-mail: jelenaz@,visokaturisticka.edu.rs

6 Stevan Barović, Direktor, Hotel HERITAGE, Ulica Mije Kovčevića br. 7a, Beograd, E-mail: director@heritagebelgrade.com

EP 2016 (63) 4 (1347-1363) 